Original paper

DOI: 10.2478/agri-2019-0013

\title{
ASSESSMENT OF THE CONTAMINATION LEVEL OF A PODZOLIZED CHERNOZEM WITH NUCLIDES IN A LONG-TERM LAND USE
}

\author{
HRYGORII HOSPODARENKO, IHOR PROKOPCHUK*, OLGA NIKITINA, \\ VITALII LIUBYCH
}

Uman National University of Horticulture, Ukraine

HOSPODARENKO, H. - PROKOPCHUK, I. - NIKITINA, O. - LIUBYCH, V.: Assessment of the contamination level of a podzolized chernozem with nuclides in a long-term land use. Agriculture (Polnohospodárstvo), vol. 65, 2019 , no. 3, pp. $128-135$.

Prolonged systematic application of mineral fertilisers contributes to increasing the yielding capacity of agricultural crops. However, it can lead to significant changes in the composition, properties and formation of agricultural soil regimes. The findings of the research have shown that the application of mineral fertilisers leads to the change of radioactive nuclides content in the soil. The research was conducted under conditions of a long-term stationary field experiment (Uman, Ukraine), using different rates of mineral fertilisers $\mathrm{N}_{45} \mathrm{P}_{45} \mathrm{~K}_{45}, \mathrm{~N}_{90} \mathrm{P}_{90} \mathrm{~K}_{90}$ and $\mathrm{N}_{135} \mathrm{P}_{135} \mathrm{~K}_{135}$. Soil samples (podzolized chernozem) were selected from the depths of $0-20,20-40$ and $40-60 \mathrm{~cm}$. Specific activity of radionuclides was determined by the spectrometric analysis. Using experimental results we have demonstrated that under a long-term application (50 years) different rates of mineral fertilisers effect the specific activity of radioactive isotopes in the soil $\left({ }^{226} \mathrm{Ra},{ }^{232} \mathrm{Th},{ }^{40} \mathrm{~K},{ }^{137} \mathrm{Cs},{ }^{90} \mathrm{Sr}\right)$. The specific activity of radionuclides in a podzolized chernozem and in winter wheat grain was established. Winter wheat plants accumulated ${ }^{232} \mathrm{Th}$ at the highest levels, but the use of fertilisers reduced it in a larger mass of the crop. The absorption of radioactive nuclides by winter wheat grain grown after peas and silage corn depending on fertilisation changed similar to growing it after clover as a previous crop. According to the data of specific activity of radioactive nuclides in the soil and winter wheat grain, the coefficient of their biological absorption was calculated.

Key words: radioactive isotopes, radium, thorium, potassium, cesium, strontium, specific activity of radioactive nuclides

At present, anthropogenic pressure on the environment is quite substantial. In particular, the use of fertilisers as part of the intensification of agricultural production gave rise to a number of new problems, making the ecological problem the most acute. Numerous studies have shown that different fertilisers have different effects on soil properties. They enter into complex interactions with the soil, leading to various transformations that depend on a number of factors: properties of fertiliser materials and soil, weather conditions, agricultural technologies, cultivated crops, etc. (Andrews et al. 2002;
Clark et al. 1998; Hrčková et al. 2018; Šimanský 2016). It is established that a long-term period of intensive agricultural use of the territories with high often unreasonable man-caused pressure has led to significant changes in the composition, properties and formation of arable soil regimes (Tobiašová et al. 2013).

However, the negative effect of fertilisers is often exaggerated. In the environmental sense, they cannot be equated with pesticides or man-made contaminants (Petrenko et al. 2017). The development of rational plant nutrition systems should include

Ihor Prokopchuk, Candidate of Agricultural Science, associate professor (*Corresponding author), Uman National University of Horticulture, 1 Institutska St., Uman, Cherkassy region, Ukraine. E-mail: pivotbi@ukr.net

(C) 2019 Authors. This is an open access article licensed under the Creative Commons Attribution-NonComercial-NoDerivs License

(http://creativecommons.org/licenses/by-nc-nd/3.0/). 
the obligatory assessment of the possible negative impact on agrocenosis and the ways to minimize it. Knowing special features of sorption, migration and translocation of toxicants in the soil helps to avoid unwanted phenomena and provide high efficiency of fertilisers (Fateev \& Zakharova 2005).

At present, the development of agriculture is impossible without the application of fertilisers which allow to increase soil fertility, yielding capacity and improve the quality of agricultural products. The yield increase is ensured by $50 \%$ due to their application (Hospodarenko 2018).

First of all, the negative influence of fertilisers on the environment is can be explained by their chemical composition and the presence of ballast substances (Begey \& Shuvar 2007; Taylor et al. 2016). When applying fertilisers under each crop, it is necessary to take into account the maximum permissible concentrations of chemical elements in the soil.

Consequently, in agriculture, along with improving yielding capacity and product quality, the studies aimed at preserving and protecting the environment against technogenic pollution should be considered relevant. It is necessary to introduce environmental resource-saving technologies that would ensure the maintenance of clean soil, water and air (Begey \& Shuvar 2007).

In the literature there is practically no data on theradioactivity levels of potassium fertilisers. It is known that $1 \mathrm{~g}$ of potassium accounts for $29.6 \mathrm{~Bq}$ of ${ }^{40} \mathrm{~K}$. Radioactive potassium $\left({ }^{40} \mathrm{~K}\right)$ has a half-life of $1.2 \times 10^{9}$ years. It is characterized by a beta-negative decay type with the energy of $1.32 \mathrm{MeV}(88.4 \%)$ and partial gamma radiation (K-capture) with the energy of $1.46 \mathrm{MeV}$ (11.6\%) (Hussain \& Hussain 2011). The content of ${ }^{40} \mathrm{~K}$ in the soil can vary within a wide range $(100-750 \mathrm{~Bq} / \mathrm{kg})$. Potassium isotopes are usually found in soil in a strongly bound form and have a low rate of transition to plants. In nature potassium exists in the form of three isotopes ${ }^{39} \mathrm{~K}$ $(93.1 \%),{ }^{41} \mathrm{~K}(6.9 \%)$ and radioactive ${ }^{40} \mathrm{~K}(0.012 \%)$. Radiation of ${ }^{40} \mathrm{~K}$ makes up only $12 \%$ in the general background of natural sources of radiation (Tzortzis et al. 2004).

The most dangerous radionuclides are ${ }^{137} \mathrm{Cs}$ and ${ }^{90} \mathrm{Sr}$ due to their active inclusion in the circulation of a trophic chain. The migration of these radionuclides in the soil-plant system leads to their accumulation in plant products. To reduce the transition of ${ }^{137} \mathrm{Cs}$ into plant products, it is necessary to apply mineral (especially potassium) and organic fertilisers and to carry out the liming of soils. The analysis of the specific activity of ${ }^{137} \mathrm{Cs}$ and ${ }^{90} \mathrm{Sr}$ in the vegetative mass of buckwheat has shown that the level of their concentration is influenced by the soil acidity and fertiliser system. Thus, there is a decrease of the specific activity of ${ }^{137} \mathrm{Cs}$ in winter wheat grain by $18-30 \%$ in variants with organic-mineral fertiliser system. This is mainly due to its binding with organic substance (Trembitska 2010).

The aim of the research was to investigate the degree of nuclide pollution of a podzolized chernozem under a long-term land use in order to determine the transformation of radionuclides in winter wheat grain.

\section{MATERIAL AND METHODS}

The research was carried out on the experimental field of Uman National University of Horticulture in the stationary experiment of the Department of Agrochemistry and Soil Science. The experiment was launched in 1964, and it is based on a 10-field crop rotation extended in time and space (spring barley + meadow clover, meadow clover, winter wheat, sugar beet, corn, peas, winter wheat, silage corn, winter wheat, sugar beet). The object of the research was a podzolized clay-loam black soil of the experimental field. Mineral fertiliser system was used $\left(\mathrm{N}_{45} \mathrm{P}_{45} \mathrm{~K}_{45} ; \mathrm{N}_{90} \mathrm{P}_{90} \mathrm{~K}_{90} ; \mathrm{N}_{135} \mathrm{P}_{135} \mathrm{~K}_{135}\right)$. Fertiliser rates were applied in the form of ammonium nitrate, granulated superphosphate, mixed potassium salt and potassium chloride. The total area of the plot was $180 \mathrm{~m}^{2}$, the experimental plot covered $100 \mathrm{~m}^{2}$, the experiment was repeated three times on the same location. Winter wheat variety Favoritka was cultivated. Wheat grain samples were taken at the stage of full maturity.

Before the experiment the soil was under a longterm cultivation under field crops. Soils samples taken before the experiment (1964) had the following parameters: content of physical clay $-66.5 \%$, base saturation $-95 \%$, humus content $-3.31 \%$; content of easily hydrolysable organic nitrogen (according to the Tjurin - Kononova method); mobile com- 
pounds of phosphorus and potassium (according to Chirikov method) - 122 and $135 \mathrm{mg} / \mathrm{kg}$ respectively; $\mathrm{pH}_{\mathrm{KCl}}-6.2$. Soil was characterized by such indicators at the time of setting up the experiment.

The soil samples were taken by earth boring machine from the layers at the depth of $0-20,20-40$ and $40-60 \mathrm{~cm}$ during 2015-2017. The experiment had three repetitions. The coefficient of biological absorption (CBA) of heavy metals in grain was determined by the formula (Baron et al. 2006).

$$
C B A=\frac{C}{E},
$$

where: $\mathrm{C}$ - content of the chemical element in grain $[\mathrm{mg} / \mathrm{kg}] ; \mathrm{E}$-content of the element in the soil $[\mathrm{mg} / \mathrm{kg}]$.

The method of spectrometric analysis was used to study specific activity of radionuclides (spectrometer - SEG-001, SEB-01-150). Statistical data processing was carried out by using the software Microsoft Excel 2010 and STATISTICA 10.

\section{RESULTS}

The application of fertilisers has rather active influence on the soil. The presence of various toxic impurities, unsatisfactory quality, as well as pos- sible violations of the application technology can lead to significant negative consequences. Failure to adhere to scientifically grounded application measures of fertilisers, imperfect methods of their introduction may have a negative impact on individual components of the biosphere, on the state of the environment and on a man (Boukhenfouf \& Boucenna 2011; Alshahri \& Alqahtani 2015). The level of radionuclide accumulation is inversely proportional to the soil fertility level: the higher the fertility is , the lower is the soil resistance to radionuclide contamination (Howard 2000).

Data in Table 1 show that the specific activity of radioactive isotopes increases with an increase in the amount of applied fertilisers in the soil. The use of triple rate of fertilisers increased radionuclide content compared to the variant without the application of fertilisers: ${ }^{226} \mathrm{Ra}$ by $26 \%,{ }^{232} \mathrm{Th}$ by $118 \%,{ }^{40} \mathrm{~K}$ by $30 \%,{ }^{137} \mathrm{Cs}$ by $26 \%$ and ${ }^{90} \mathrm{Sr}$ by $6 \%$.

As a result of the dispersion analysis, it was established that the impact of the previous plant on the content of radioactive nuclides was the highest since the partial eta-squared was 0.97 and the one of fertiliser was the smallest (0.46) (Figure 1). Important quantitative indicators are absorption completeness of radionuclides (sorption) and stability of their fixation in the absorbed state. For example, if we compare the stability of fixation of ${ }^{90} \mathrm{Sr}$ and ${ }^{137} \mathrm{Cs}$ in the absorbed state, it turns out that ${ }^{90} \mathrm{Sr}$ is displaced

Partial eta-squared

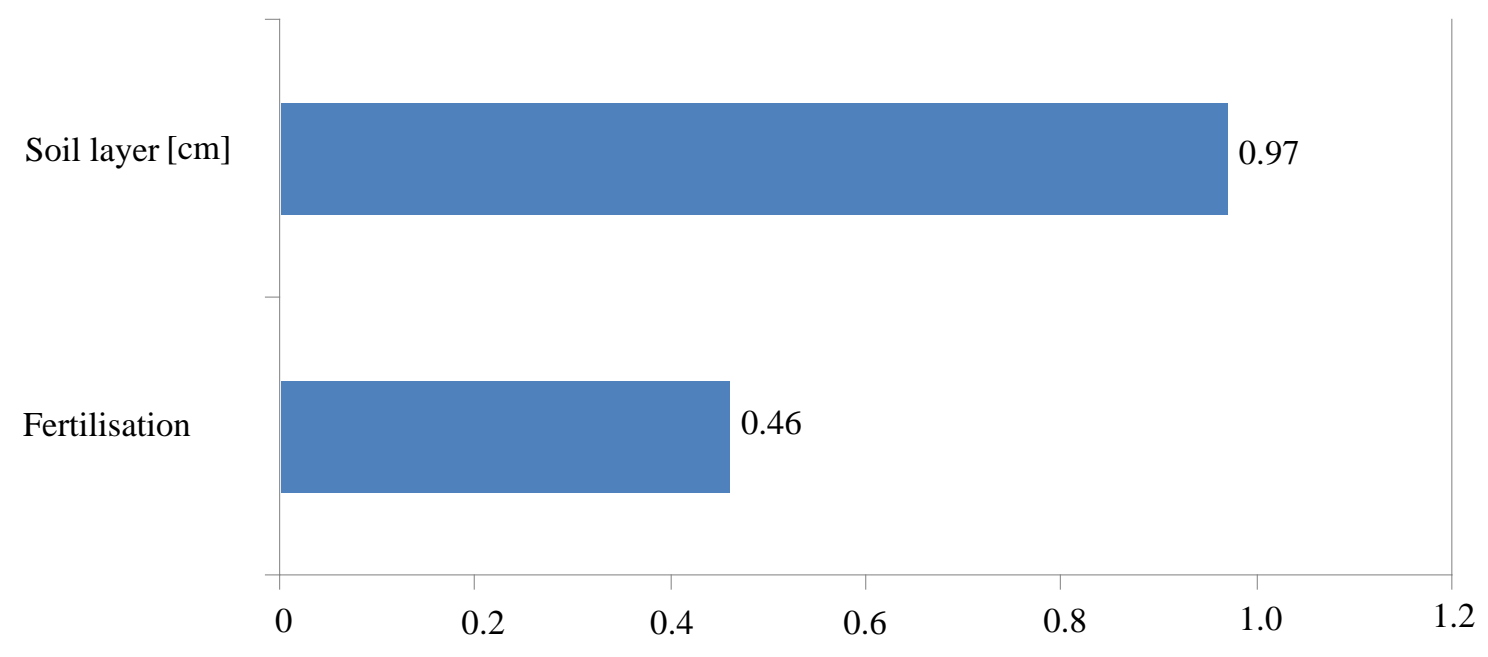

Figure 1. The effect level of the investigated factors on the specific activity of radionuclides in the soil 
in greater quantity than ${ }^{137} \mathrm{Cs}$ (so, absorbed cesium is firmly fixed). It is confirmed by the data obtained from the research. The stability of radionuclide fixation is uneven on different soils. They are fixed better in black soil.

In general, unlike strontium, cesium is better sorbed (fixed) by minerals, especially by clay. The radiation hazard of strontium is 6 times higher than that of cesium under the same level of soil contamination. In order to reduce the degree of migration, such agrochemical measures are carried out as liming acidic soils, poor in metabolic calcium and introducing organic fertilisers (humus, peat and manure). To reduce strontium uptake phosphorus fertilisers are used, and to reduce cesium uptake - potassium fertilisers.

The presence of two natural radioactive nuclides is characteristic for potassium fertilisers ${ }^{226} \mathrm{Ra}$ and ${ }^{40} \mathrm{~K}$ ). In this case, the main radionuclide is ${ }^{40} \mathrm{~K}$ (Kondo et al. 2015). Radioactive potassium $\left({ }^{40} \mathrm{~K}\right)$ is the most common among the natural radioactive isotopes. Its general activity in the earth's crust is greater than the activity of all other isotopes taken together. It is widely distributed in soils, especially clay ones, where it is firmly retained as a result of sorption processes. Due to the content of ${ }^{40} \mathrm{~K}(0.0119 \%)$ one gram of natural potassium is characterized by the activity of 29.6 Bq (Kaste et al. 2003).

The use of potassium fertilisers with residual natural radioactivity does not significantly increase the radioactivity of agricultural crops, but sometimes it increases by several times. Such phenomenon is usually observed in young plants under the application of high rates of potassium fertilisers (Becegato et al. 2008).

Specific activity of potassium and radium in the soil depended on the rate of potassium fertilisers. Specific activity of ${ }^{40} \mathrm{~K}$ increased from 12 to $30 \%$ depending on the rate of applied fertilisers and the specific activity of ${ }^{226} \mathrm{Ra}$ increased from 11 to $26 \%$.

$\mathrm{T}$ a

Specific activity of radionuclides in the soil after long-term growing (50 years) of field crops using different fertilisers (2015-2017) [Bq/kg]

\begin{tabular}{|l|c|c|c|c|c|c|}
\hline \multirow{2}{*}{ Experiment variant } & \multirow{2}{*}{ Soil layer [cm] } & \multicolumn{3}{|c|}{ Radionuclide } \\
\cline { 3 - 7 } & & ${ }^{226} \mathrm{Ra}$ & ${ }^{232} \mathrm{Th}$ & ${ }^{40} \mathrm{~K}$ & ${ }^{137} \mathrm{Cs}$ & ${ }^{90} \mathrm{Sr}$ \\
\hline \multirow{3}{*}{ Without fertilisers } & $20-20$ & $25.8 \pm 0.5^{*}$ & $20.4 \pm 0.7^{*}$ & $105.1 \pm 4.1^{*}$ & $8.4 \pm 0.4^{*}$ & $3.1 \pm 0.05^{*}$ \\
& $40-60$ & $20.1 \pm 0.6^{*}$ & $20.6 \pm 0.5^{*}$ & $77.3 \pm 2.8^{*}$ & $7.2 \pm 0.4^{*}$ & $2.0 \pm 0.04^{*}$ \\
& $0-20$ & $28.6 \pm 0.5^{*}$ & $30.4 \pm 0.8^{*}$ & $118.0 \pm 3.7^{*}$ & $9.0 \pm 0.2^{*}$ & $3.2 \pm 0.03^{*}$ \\
& $20-40$ & $22.3 \pm 0.6^{*}$ & $20.6 \pm 0.5^{*}$ & $81.2 \pm 1.9^{*}$ & $7.4 \pm 0.4^{*}$ & $2.0 \pm 0.04^{*}$ \\
& $40-60$ & $15.2 \pm 0.7^{*}$ & $19.6 \pm 0.7^{*}$ & $56.4 \pm 4.2^{*}$ & $4.5 \pm 0.4^{*}$ & $1.8 \pm 0.03^{*}$ \\
\hline \multirow{3}{*}{$\mathrm{N}_{45} \mathrm{P}_{45} \mathrm{~K}_{45}$} & $0-20$ & $30.7 \pm 0.8^{*}$ & $38.6 \pm 0.6^{*}$ & $128.1 \pm 4.4^{*}$ & $9.9 \pm 0.3^{*}$ & $3.1 \pm 0.03^{*}$ \\
& $20-40$ & $24.8 \pm 0.9^{*}$ & $26.3 \pm 0.5^{*}$ & $95.9 \pm 3.6^{*}$ & $7.6 \pm 0.3^{*}$ & $2.2 \pm 0.04^{*}$ \\
$\mathrm{~N}_{90} \mathrm{P}_{90} \mathrm{~K}_{90}$ & $40-60$ & $15.2 \pm 0.9^{*}$ & $20.1 \pm 0.6^{*}$ & $58.7 \pm 1.6^{*}$ & $4.6 \pm 0.3^{*}$ & $1.9 \pm 0.05^{*}$ \\
\hline & $0-20$ & $32.6 \pm 0.7^{*}$ & $44.6 \pm 0.5^{*}$ & $136.2 \pm 1.7^{*}$ & $10.6 \pm 0.3^{*}$ & $3.3 \pm 0.04^{*}$ \\
& $20-40$ & $27.1 \pm 0.7^{*}$ & $30.6 \pm 0.3^{*}$ & $110.0 \pm 3.0^{*}$ & $7.8 \pm 0.3^{*}$ & $2.4 \pm 0.03^{*}$ \\
& $40-60$ & $15.1 \pm 0.3^{*}$ & $20.8 \pm 0.7^{*}$ & $61.2 \pm 3.2^{*}$ & $4.5 \pm 0.4^{*}$ & $1.9 \pm 0.05^{*}$ \\
\hline
\end{tabular}

Note: ${ }^{*}$ - insignificant variation $(\mathrm{V}=0-10 \%)$ 
Downward the soil profile their specific activity decreased and at the depth of $4,060 \mathrm{~cm}$ it was 2 times lower than in the upper layer of $0-20 \mathrm{~cm}$.

Safety of potassium fertilisers was established in a long-term field experiment. Potassium radiation, creating natural radiation background, is not limited by current norms and is not dangerous to human health.

Application of fertilisers in the field crop rotation changes the specific activity of radioisotopes in winter wheat grain (Table 2).

When cultivating winter wheat after silage corn, specific activity is lower compared to other previous crops (clover and peas). The specific activity of ${ }^{232} \mathrm{Th}$ in winter wheat grain was lower compared to ${ }^{40} \mathrm{~K}(18.1-22.8 \mathrm{~Bq} / \mathrm{kg})$ depending on the rate of fertilisers and previous plants. Also, it has been found that ${ }^{232} \mathrm{Th}$ absorption was higher under growing wheat after clover and peas $(19.6-22.8 \mathrm{~Bq} / \mathrm{kg}$ of grain) than under growing wheat after silage corn $(18.1-19.8 \mathrm{~Bq} / \mathrm{kg})$.

Specific activity of ${ }^{226} \mathrm{Ra}$ was almost unaffected by the investigated components of agricultural technologies of winter wheat cultivation. Its activity varied within a small range $(6.0-6.8 \mathrm{~Bq} / \mathrm{kg})$.

${ }^{90} \mathrm{Sr}$ and ${ }^{137} \mathrm{Cs}$ radioisotopes are easily included in the migration processes in agricultural chains because their chemical properties are similar like those in calcium and potassium, that play an important role in the biosphere.

${ }^{137} \mathrm{Cs}$ and ${ }^{90} \mathrm{Sr}$ specific activity in winter wheat grain was the lowest compared to other radionu-

T a b 1 e 2

Specific activity of radionuclides in winter wheat grain using different fertilisers in the field crop rotation and preceding crops (2015-2017) [Bq/kg of dry mass]

\begin{tabular}{|c|c|c|c|c|c|c|}
\hline \multirow{2}{*}{\multicolumn{2}{|c|}{ Experiment variant (Factor A) }} & \multicolumn{5}{|c|}{ Radioactive nuclide } \\
\hline & & ${ }^{40} \mathrm{~K}$ & ${ }^{232} \mathrm{Th}$ & ${ }^{226} \mathrm{Ra}$ & ${ }^{137} \mathrm{Cs}$ & ${ }^{90} \mathrm{Sr}$ \\
\hline \multicolumn{7}{|c|}{ Clover as a preceding crop (Factor B) } \\
\hline \multicolumn{2}{|c|}{ Without fertilisers (control variant) } & $68.1 \pm 1.5^{*}$ & $19.6 \pm 0.5^{*}$ & $6.5 \pm 0.03 *$ & $1.7 \pm 0.06^{*}$ & $0.8 \pm 0.04^{*}$ \\
\hline \multicolumn{2}{|c|}{$\mathrm{N}_{45} \mathrm{P}_{45} \mathrm{~K}_{45}$} & $69.3 \pm 2.3^{*}$ & $19.5 \pm 0.2 *$ & $6.4 \pm 0.04 *$ & $1.7 \pm 0.05^{*}$ & $0.8 \pm 0.04^{*}$ \\
\hline \multicolumn{2}{|c|}{$\mathrm{N}_{90} \mathrm{P}_{90} \mathrm{~K}_{90}$} & $74.5 \pm 1.3^{*}$ & $20.2 \pm 0.4^{*}$ & $6.6 \pm 0.03 *$ & $1.9 \pm 0.05 *$ & $0.9 \pm 0.03^{*}$ \\
\hline \multicolumn{2}{|c|}{$\mathrm{N}_{135} \mathrm{P}_{135} \mathrm{~K}_{135}$} & $87.2 \pm 1.5^{*}$ & $22.8 \pm 0.5^{*}$ & $6.7 \pm 0.03 *$ & $2.1 \pm 0.03 *$ & $1.0 \pm 0.04^{*}$ \\
\hline \multicolumn{7}{|c|}{ Peas as a preceding crop } \\
\hline \multicolumn{2}{|c|}{ Without fertilisers (control variant) } & $68.4 \pm 1.9^{*}$ & $19.5 \pm 0.7 *$ & $6.6 \pm 0.03 *$ & $1.7 \pm 0.04 *$ & $0.8 \pm 0.02 *$ \\
\hline \multicolumn{2}{|c|}{$\mathrm{N}_{45} \mathrm{P}_{45} \mathrm{~K}_{45}$} & $70.1 \pm 1.4^{*}$ & $19.8 \pm 0.7^{*}$ & $6.7 \pm 0.04^{*}$ & $1.8 \pm 0.06^{*}$ & $0.8 \pm 0.04^{*}$ \\
\hline \multicolumn{2}{|c|}{$\mathrm{N}_{90} \mathrm{P}_{90} \mathrm{~K}_{90}$} & $76.2 \pm 1.6^{*}$ & $20.4 \pm 0.4^{*}$ & $6.7 \pm 0.02 *$ & $1.9 \pm 0.04^{*}$ & $1.0 \pm 0.04^{*}$ \\
\hline \multicolumn{2}{|c|}{$\mathrm{N}_{135} \mathrm{P}_{135} \mathrm{~K}_{135}$} & $86.4 \pm 2.2 *$ & $21.7 \pm 0.3 *$ & $6.8 \pm 0.03 *$ & $2.1 \pm 0.02 *$ & $1.1 \pm 0.04^{*}$ \\
\hline \multicolumn{7}{|c|}{ Silage as a preceding crop } \\
\hline \multicolumn{2}{|c|}{ Without fertilisers (control variant) } & $68.3 \pm 1.4^{*}$ & $18.1 \pm 0.7^{*}$ & $6.0 \pm 0.03 *$ & $1.7 \pm 0.05^{*}$ & $0.8 \pm 0.02 *$ \\
\hline \multicolumn{2}{|c|}{$\mathrm{N}_{45} \mathrm{P}_{45} \mathrm{~K}_{45}$} & $69.8 \pm 1.8^{*}$ & $18.2 \pm 0.7^{*}$ & $6.1 \pm 0.03^{*}$ & $1.7 \pm 0.06^{*}$ & $0.8 \pm 0.03^{*}$ \\
\hline \multicolumn{2}{|c|}{$\mathrm{N}_{90} \mathrm{P}_{90} \mathrm{~K}_{90}$} & $71.7 \pm 1.4^{*}$ & $19.3 \pm 0.5^{*}$ & $6.1 \pm 0.03^{*}$ & $1.7 \pm 0.06^{*}$ & $0.9 \pm 0.03^{*}$ \\
\hline \multicolumn{2}{|c|}{$\mathrm{N}_{135} \mathrm{P}_{135} \mathrm{~K}_{135}$} & $77.6 \pm 1.4^{*}$ & $19.8 \pm 0.4^{*}$ & $6.1 \pm 0.03 *$ & $1.8 \pm 0.03 *$ & $1.0 \pm 0.02 *$ \\
\hline \multirow{2}{*}{$L S D_{0.05}$} & $A$ & 1.7 & 0.5 & 0.2 & 0.1 & 0.1 \\
\hline & $B$ & 1.4 & 0.4 & 0.2 & 0.1 & 0.1 \\
\hline \multicolumn{2}{|l|}{$M P C$} & - & - & - & 80 & 140 \\
\hline
\end{tabular}

$M P C$ - maximum permissible concentration; $P=0.002$

Note: $*$ - insignificant variation $(\mathrm{V}=0-10 \%)$ 
$\mathrm{T}$ a

Coefficient of biological absorption of radioactive nuclides by winter wheat grain after a long-term application of fertilisers (50 years) in the field crop rotation and preceding crops

\begin{tabular}{|c|c|c|c|c|c|c|}
\hline \multirow{2}{*}{\multicolumn{2}{|c|}{$\begin{array}{l}\text { Experiment variant } \\
\text { (Factor A) }\end{array}$}} & \multicolumn{5}{|c|}{ Radioactive nuclide } \\
\hline & & ${ }^{40} \mathrm{~K}$ & ${ }^{232} \mathrm{Th}$ & ${ }^{226} \mathrm{Ra}$ & ${ }^{137} \mathrm{Cs}$ & ${ }^{90} \mathrm{Sr}$ \\
\hline \multicolumn{7}{|c|}{ Clover as a preceding crop (Factor B) } \\
\hline \multicolumn{2}{|c|}{ Without fertilisers (control variant) } & 0.65 & 0.96 & 0.25 & 0.20 & 0.26 \\
\hline \multicolumn{2}{|l|}{$\mathrm{N}_{45} \mathrm{P}_{45} \mathrm{~K}_{45}$} & 0.59 & 0.64 & 0.22 & 0.19 & 0.25 \\
\hline \multicolumn{2}{|l|}{$\mathrm{N}_{90} \mathrm{P}_{90} \mathrm{~K}_{90}$} & 0.60 & 0.55 & 0.22 & 0.20 & 0.28 \\
\hline \multicolumn{2}{|l|}{$\mathrm{N}_{135} \mathrm{P}_{135} \mathrm{~K}_{135}$} & 0.64 & 0.51 & 0.21 & 0.20 & 0.30 \\
\hline \multicolumn{7}{|c|}{ Peas as a preceding crop } \\
\hline \multicolumn{2}{|c|}{ Without fertilisers (control variant) } & 0.65 & 0.96 & 0.26 & 0.20 & 0.27 \\
\hline \multicolumn{2}{|l|}{$\mathrm{N}_{45} \mathrm{P}_{45} \mathrm{~K}_{45}$} & 0.60 & 0.66 & 0.24 & 0.20 & 0.26 \\
\hline \multicolumn{2}{|l|}{$\mathrm{N}_{90} \mathrm{P}_{90} \mathrm{~K}_{90}$} & 0.61 & 0.57 & 0.23 & 0.19 & 0.31 \\
\hline \multicolumn{2}{|l|}{$\mathrm{N}_{135} \mathrm{P}_{135} \mathrm{~K}_{135}$} & 0.64 & 0.49 & 0.22 & 0.19 & 0.32 \\
\hline \multicolumn{7}{|c|}{ Silage corn as a preceding crop } \\
\hline \multicolumn{2}{|c|}{ Without fertilisers (control variant) } & 0.66 & 0.95 & 0.25 & 0.21 & 0.29 \\
\hline \multicolumn{2}{|l|}{$\mathrm{N}_{45} \mathrm{P}_{45} \mathrm{~K}_{45}$} & 0.63 & 0.71 & 0.22 & 0.19 & 0.27 \\
\hline \multicolumn{2}{|l|}{$\mathrm{N}_{90} \mathrm{P}_{90} \mathrm{~K}_{90}$} & 0.60 & 0.61 & 0.22 & 0.18 & 0.28 \\
\hline \multicolumn{2}{|l|}{$\mathrm{N}_{135} \mathrm{P}_{135} \mathrm{~K}_{135}$} & 0.59 & 0.51 & 0.21 & 0.18 & 0.31 \\
\hline \multirow{2}{*}{$L S D_{0.05}$ by factors } & $A$ & 0.02 & 0.03 & 0.01 & 0.01 & 0.02 \\
\hline & $B$ & 0.01 & 0.02 & 0.01 & 0.01 & 0.01 \\
\hline
\end{tabular}

$P=0.002$

clides, correspondingly from 1.7 to 2.1 and from 0.8 to $1.1 \mathrm{~Bq} / \mathrm{kg}$, depending on the agricultural technology of cultivation. This indicates that a long-term application of fertilisers in the field crop rotation at mentioned rates is safe. At the same time, ${ }^{137} \mathrm{Cs}$ specific activity was $40-47$ times and ${ }^{90} \mathrm{Sr}$ specific activity was $127-145$ times lower than the maximum permissible concentration.

It is found that the application of potassium fertilisers contributes to a significant reduction of radioactive cesium content in the main as well as non-market part of wheat yields compared to the control variant (Pettigrew 2008). Potassium fertilisers are an effective and economically justifiable measure to reduce ${ }^{137} \mathrm{Cs}$ and ${ }^{90} \mathrm{Sr}$ penetration in plant products.

A long-term application of potassium fertilisers increases the radioactivity of the soil due to the content of ${ }^{40} \mathrm{~K}$ and ${ }^{226} \mathrm{Ra}$. However, the important ecological function of potassium is antagonism in relation to radioactive ${ }^{137} \mathrm{Cs}$ and ${ }^{90} \mathrm{Sr}$. Many scientists note the significant role of potassium fertilisers in reducing the intensity and migration of radionuclides in the soil-plant system. Potassium inhibits ${ }^{137} \mathrm{Cs}$ transfer into crops of agrocenoses. The greatest effect is achieved with the application of high rates of potassium fertilisers (Aleksakhin et al. 1992; Hospodarenko 2018).

According to the data of specific activity of radioactive nuclides in the soil and in winter wheat grain presented in Table 3, the coefficient of biological absorption (CBA) of radionuclides was calculated (Table 3).

Winter wheat plants accumulated ${ }^{232} \mathrm{Th}$ most of all. However, the use of fertilisers reduced it in a larger mass of the crop. Thus, in the variant 
without fertilisers, the coefficient of biological absorption of ${ }^{232} \mathrm{Th}$ by winter wheat grain after clover was 0.96 and in the mineral fertiliser system it was $0.51-0.64$ or less by $33-47 \%$. Winter wheat grain accumulated the smallest amounts of ${ }^{137} \mathrm{Cs},{ }^{90} \mathrm{Sr}$ and ${ }^{226} \mathrm{Ra}$.

The absorption of radioactive nuclides by winter wheat grain after peas and silage corn depending on fertilisers varied similar to that after the clover as a preceding plant.

The results of the research are ambiguous when compared to the similar studies that were published. Thus, in research (Fateev \& Zakharova 2005), specific activity of ${ }^{137} \mathrm{Cs}$ under the application of $\mathrm{N}_{90} \mathrm{P}_{60} \mathrm{~K}_{90}$ decreased from $188.2 \mathrm{~Bq} / \mathrm{kg}$ to $119.5 \mathrm{~Bq} / \mathrm{kg}$. In studies (Tsybul'ka et al. 2014) conducted on peat soils, the application of potassium fertilisers reduced the activity of this radioisotope in wheat grain by $20-30 \%$, but the application of $\mathrm{N}_{60-120}$ increased it by $4-9 \%$. It is obvious that specific activity of radionuclides in wheat grain varies not only after the use of fertilisers, but it also depends on the level of soil fertility created by long-term fertilisation.

\section{CONCLUSIONS}

Absorption of radionuclides by topsoil prevents them from moving through its profile and further penetration into groundwater. Thus, specific activity of radionuclides was two times lower at the depth of $40-60 \mathrm{~cm}$ than in the soil layer of $0-20 \mathrm{~cm}$. This indicates that radioisotopes are fixed in the upper layers of the soil which in its turn increases their penetration into crop products.

The level of ${ }^{137} \mathrm{Cs}$ uptake by winter wheat plants from the soil is the highest, while the level of ${ }^{90} \mathrm{Sr}$ uptake is the lowest. The coefficient of biological absorption of ${ }^{232} \mathrm{Th}$ is significantly reduced with the improvement of the conditions of plant growth and plant development. The absorption of ${ }^{40} \mathrm{~K}$ from the soil is significant but it is safe for human health. Contamination of crop products with radionuclides depends on the type and properties of soils, types, forms and rates of fertilisers and the duration of their application. Therefore, the radionuclide concentration in plants on different soils in different soil-climatic zones may be different at the same level of pollution.
Long-term application of potassium fertilisers increases the soil radioactivity due to the content of ${ }^{40} \mathrm{~K}$ and ${ }^{226} \mathrm{Ra}$ but this radiation is safe for human health. In addition, potassium has an important ecological function being the antagonist in relation to radioactive ${ }^{137} \mathrm{Cs}$ and ${ }^{90} \mathrm{Sr}$.

The analysis of the specific activity of radionuclides in winter wheat grain indicates that a longterm application of fertilisers (50 years) in the field crop rotation at the indicated fertiliser rates is safe.

\section{REFERENCES}

ALEKSAKHIN, R.M. - MOISEEV, I.T. - TIKHOMIROV, F.A. 1992. The behavior of ${ }^{137} \mathrm{Cs}$ in the soil-plant system and the effect of fertilizer application on the accumulation of radionuclides in the crop. In Agrochemistry, no. 8, pp. $127-138$.

ALSHAHRI, F. - ALQAHTANI, M. 2015. Chemical fertilizers as a source of ${ }^{238} \mathrm{U},{ }^{40} \mathrm{~K},{ }^{226} \mathrm{Ra},{ }^{222} \mathrm{Rn}$ and trace metal pollutant of the environment in Saudi Arabia. In Environmental Science and Pollution Research, vol. 22, no. 11, pp. 8339-8348. DOI: 10.1007/s11356-014-3984-3

ANDREWS, S. - MITCHELL, J. - MANCINELLI, R. KARLEN, D. - HARTZ, T. 2002. On-farm assessment of soil quality in California's Central Valley. In Agronomy Journal, vol. 94, no. 1, pp. 12-23.

BARON, S. - CARIGNAN, J. - PLOQUIN, A. 2006. Dispersion of heavy metals (metalloids) in soils from 800-year old pollution (Mont-Lozere, France). In Environtal Science \& Technology, vol. 40, no. 17, pp. 5319-5326. DOI: 10.1021/ es0606430

BECEGATO, V.A. - FERREIRA, F.J.F. - MACHADO, W.C.P. 2008. Concentration of radioactive elements (U, Th and K) derived from phosphatic fertilizers in cultivated soils. In Brazilian Archives of Biology and Technology, vol. 51, no. 6, pp. 1255-1266. DOI.org/10.1590/S151689132008000600022

BEGEY, S.V. - SHUVAR, I.S. 2007. Ecological agriculture. Lviv: "New World-2000", pp. 428 (in Ukrainian).

BOUKHENFOUF, W. - BOUCENNA, A. 2011. The radioactivity measurements in soils and fertilizers using gamma spectrometry technique. In Journal of Environmental Radioactivity, vol. 102, no. 4, pp. 336-339. DOI 10.1016/j. jenvrad.2011.01.006. Epub 2011 Feb 22

CLARK, M. - HORWATH, W. - SHENNAN, C. - SCOW, K. 1998. Changes in soil chemical properties resulting from organic and low-input farming practices. In Agronomy Journal, vol. 90, no. 5, pp. 662-671. DOI: 10.2134/agronj 1998.00021962009000050016x

GAYCHENKO, V.A. - GUDKOV, I.N. - KASHPAROV, V.O. - KITSNO, V.O. - LAZAREV, N.N. 2009. Workshop on radiobiology and radioecology. Kyiv, $253 \mathrm{p}$.

FATEEV, A.I. - ZAKHAROVA, M.A. 2005. Fundamentals of the application of micro fertilizers. Kharkiv: KP Typography, $134 \mathrm{p}$.

HOSPODARENKO, G.M. 2018. Agrochemistry. Kiev: SIC Group Ukraine LLC., 560 p. (in Ukrainian).

HOWARD, B. 2000. The concept of radio ecological sensitivity. In Radiation Protection Dosimetry, vol. 92, pp. 29-34. DOI: 10.1093/oxfordjournals.rpd.a033279 
HRČKOVÁ, K. - MIHALČ́K, P. - ŽÁK, S̆. - HAS̆ANA, R. - ONDREIČKOVÁ, K. - KRAIC, J. 2018. Agronomic and economic performance of genetically modified and conventional maize. In Agriculture (Pol'nohospodárstvo), vol. 64, no. 2, pp. 87-93. DOI: 10.2478/agri-2018-0009

HUSSAIN, R.O. - HUSSAIN, H.H. 2011. Investigation of the natural radioactivity in local and imported chemical fertilizers. In Brazilian Archives of Biology and Technology, vol. 54, no. 4, pp. 777-782. DOI.org/10.1590/S151689132011000400018

KASTE, J.M. - FRIEDLAND, A.J. - STÜRUP, S. 2003. Stable and Radioactive Isotopes To Trace Atmospherically Deposited $\mathrm{Pb}$ in Montane Forest Soils. In Environmental Studies, vol. 37 , no. 16 , pp. $3560-3567$. DOI: $10.1021 /$ es026372k

KONDO, M. - MAKINO, T. - EGUCHI, T. - GOTO, A. - NAKANO, H. - TAKAI, T. - KIMURA, T. 2015. Comparative analysis of the relationship between Cs and $\mathrm{K}$ in soil and plant parts toward control of $\mathrm{Cs}$ accumulation in rice. In Soil Science and Plant Nutrition, vol. 61, pp. 144-151. DOI.org/10.1080/00380768.2014.973348

PETRENKO, V. - LIUBICH, V. - BONDAR, V. 2017. Baking quality of wheat grain as influenced by agriculture systems, weather and storing conditions. In Romanian Agricultural Research, vol. 34, pp. 69-76. DOI: 2067-5720 RAR 2017153

PETTIGREW, W.T. 2008. Potassium influences on yield and quality production for maize, wheat, soybean and cotton. In Physiologia Plantarum, vol. 133, no. 4, pp. 670-681. doi org/10.1111/j.1399-3054.2008.01073.x

ŠIMANSKÝ, V. 2016. Changes in soil organic matter parameters during the period of 18 years under different soil management practices. In Agriculture (Polnohospodárstvo), vol. 62, no. 4, pp. 149-154. DOI: 10.1515/agri-2016-0015
TAYLOR, M. - KIM, N. - SMIDT, G. - BUSBY, C. MCNALLY, S. - ROBINSON, B. - KRATZ, S. - SCHNUG, E. 2016. Trace element contaminants and radioactivity from phosphate fertiliser. In Phosphorus in Agriculture $100 \%$ Zero, pp. 231-266. doi.org/10.1007/978-94-017-7612712

TOBİAŠOVÁ, E. - ŠIMANSKÝ, V. - DĘBSKA, B. BANACH-SZOTT, M. 2013. Soil structure and soil organic matter of selected soil types in different ecosystems. In Agriculture (Pol'nohospodárstvo), vol. 59, pp. 1-8. DOI: 10.2478/agri-2013-0001

TREMBITSKA, O.I. 2010. Influence of fertilizer systems on the agricultural ecological state of sod-podzolic soils and accumulation of radiocesium by agricultural plants. In Bulletin of Institute of Grain Farming, vol. 39, pp. 107-110 (in Ukrainian).

TSYBUL'KA, N.N. - ZAITSEV, A.A. - SEMENENKO, N.N. 2014. Influence of doses of nitrogen and potassium fertilizers on ${ }^{137} \mathrm{cs}$ in grain and products spring wheat in anthropogenno-transformed peat soil. In Soil Science and Agrochemistry, vol. 1, pp. 236-250.

TZORTZIS, M. - SVOUKIS, E. - TSERTOS, H. 2004. A comprehensive study of natural gamma radioactivity levels and associated dose rates from surface soils in Cyprus. In Radiation Protection Dosimetry, vol. 109, no. 3, pp. 217-224. doi.org/10.1093/rpd/nch300

Received: March 5, 2019 Accepted: September 12, 2019 